\title{
Effect of Lipid Status on Cytoplasmic and Mitochondrial Protein Synthesis in Anaerobic Cultures of Saccharomyces cerevisiae
}

\author{
By P. A. GORDON* AND P. R. STEWART \\ Department of Developmental Biology, Research School of Biological Sciences, \\ Australian National University, Canberra, A.C.T., Australia
}

(Acepted for publication I I April I972)

\section{SUMMARY}

Saccharomyces cerevisiae grown anaerobically in the absence of unsaturated fatty acids and sterol depleted its endogenous levels of these lipids by dilution as yeast numbers and mass increased. When the levels of unsaturated fatty acids and sterol reached approximately one-quarter those found in aerobically grown cells, the organisms stopped dividing; cells then ceased generating dry weight. Concomitant with this depletion of lipids was a decline in the protein-synthesizing activity of the cell. In mitochondria this was due to a loss of high molecular weight RNA. In the cytoplasm the effect was at the level of the ribosomes but was not due to loss of integrity of ribosomal or associated RNA, nor to a decrease in the ribosome/polysome complement. When oxygen was supplied, protein synthesis in mitochondria and cytoplasm was rapidly reactivated in the absence of cell growth. This reactivation was accompanied by a rapid resynthesis of unsaturated fatty acids and ergosterol.

\section{INTRODUCTION}

Membrane-ribosome interactions may have an important role in regulating protein synthesis in mammalian cells (Takagi, Tanaka \& Ogata, 1970; and references therein) and bacteria (Hendler, 1965; Cundliffe, 1970). In facultatively anaerobic yeast (Jollow, Kellerman \& Linnane, 1968) and fungi (Gordon, Stewart \& Clark-Walker, 197I) the lipid composition of cellular membranes can be altered by anaerobic growth under conditions of lipid limitation. In Saccharomyces cerevisiae grown to lipid depletion it has been proposed that mitochondrial protein synthesis is interrupted by the altered lipid status of the cell (Vary, Stewart \& Linnane, 1970; Watson, Veitch, Haslam \& Linnane, 1971). However, promitochondria from lipid-depleted anaerobes have an unusual lipid composition (Paltauf \& Schatz, 1969; Gordon \& Stewart, 197I), suggesting altered membrane properties. Isolation of these organelles in an intact or functional state may be difficult, and this could account for the results reported with isolated promitochondria by Watson et al. (1971). A less equivocal approach to the question of the presence or absence of an active mitochondrial proteinsynthesizing system in cells is provided by the in situ method of assay of this activity described by Schatz \& Saltzgaber (1969) and Schweyen \& Kaudewitz (1970).

In this communication we report the effects of variation of concentration of essential lipid on mitochondrial and cytoplasmic protein synthesis measured in situ, and compare the effects observed with measurement in vitro of a reconstituted cytoplasmic ribosomal system. The results suggest an intimate regulatory relationship between protein synthesis and cellmembrane composition in this organism.

* Present address: Department of Medicine and Biochemistry, University of Chicago, Chicago, Illinois, U.S.A. 


\section{METHODS}

Organism and growth conditions. A diploid laboratory strain of Saccharomyces cerevisiae Hansen, cultured on semisynthetic media as described previously (Gordon \& Stewart, I97I), was grown anaerobically with or without unsaturated fatty acids (as Tween $80,5 \mathrm{ml} / \mathrm{l}$ ) and ergosterol $(20 \mathrm{mg} / \mathrm{l})$ for the times indicated. Density of cultures was determined either gravimetrically after washing the yeasts three times with water, or nephelometrically at $640 \mathrm{~nm}$ by means of a standard curve. Cell number was determined with a haemocytometer.

Aeration of anaerobic organisms. Yeast was harvested, resuspended at approximately $5 \mathrm{mg}$ dry $\mathrm{wt} / \mathrm{ml}$ in fresh medium containing galactose (1 \%,w/v) and aerated as described previously (Vary, Edwards \& Stewart, I969).

\section{Measurement in vivo of promitochondrial protein synthesis}

The method is similar to that described by Schatz \& Saltzgaber (1969). Cycloheximide to a final concentration of $10 \mu \mathrm{g} / \mathrm{ml}$ in oxygen-free solution was added to anaerobic cultures I 5 min before harvesting. Organisms were then poured on to ice, harvested by centrifugation at $2{ }^{\circ} \mathrm{C}$, washed with cold cycloheximide solution $(25 \mu \mathrm{g} / \mathrm{ml})$, and resuspended at 5 to $6 \mathrm{mg}$ dry $\mathrm{wt} / \mathrm{ml}$ in $0.05 \mathrm{M}$-potassium phosphate, $\mathrm{pH} 6.0$, containing $\mathrm{I} \%$ galactose and $25 \mu \mathrm{g}$ cycloheximide $/ \mathrm{ml}$. Yeast from aeration flasks was harvested in the same way. Erythromycin $(5 \mathrm{mg} / \mathrm{ml}$ as Ilotycin, from Eli, Lilly and Co., Sydney, Australia) was added as indicated. Suspensions of organisms were shaken at $29^{\circ} \mathrm{C}$ for 15 min under nitrogen, then $50 \mu \mathrm{Ci}$ $\mathrm{L}-\left[4,5^{-3} \mathrm{H}\right]$ leucine ( 8 to $34 \mathrm{Ci} / \mathrm{mmol}$ ) was added per $200 \mathrm{ml}$ of suspension, and incubation continued under nitrogen for $15 \mathrm{~min}$. Incorporation of label, which was linear for this time, was terminated by adding $2 \mathrm{ml}$ of $70 \mathrm{~mm}$-DL-leucine (unlabelled) $/ 200 \mathrm{ml}$ of yeast suspension, and immediately pouring on to ice. All subsequent steps were carried out at o to $4{ }^{\circ} \mathrm{C}$, using solutions containing $25 \mu \mathrm{g} /$ cycloheximide/ml. Organisms were harvested by centrifugation, washed once with water, once with $0.5 \mathrm{M}$-sorbitol-20 mM-tris chloride ( $\mathrm{pH} 7.4$ ) $-0.5 \mathrm{~mm}$ disodium EDTA (STE), then resuspended in STE at 60 to $80 \mathrm{mg}$ dry wt $/ \mathrm{ml}$. An equal volume of glass beads $(0.5 \mathrm{~mm})$ was added and the organisms broken in a Braun MSK homogenizer at top speed for $25 \mathrm{~s}$ with carbon dioxide as coolant. Breakage under these conditions was 60 to $80 \%$. Unbroken organism and debris were removed by centrifuging twice for Io min at $1000 \mathrm{~g}$. Promitochondria were sedimented at $9000 \mathrm{~g}$ for $20 \mathrm{~min}$. The promitochondrial fraction was washed three times with STE, and resuspended in this buffer at approximately Io $\mathrm{mg}$ protein $/ \mathrm{ml}$. The postmitochondrial supernatant was centrifuged at $150000 \mathrm{~g}$ for $60 \mathrm{~min}$ to yield a soluble or cytosol fraction.

\section{Centrifugation of promitochondria on sucrose density gradients}

Promitochondria were loaded on to 30 to $70 \%(\mathrm{w} / \mathrm{v})$ sucrose gradients containing $10 \mathrm{~mm}$ -

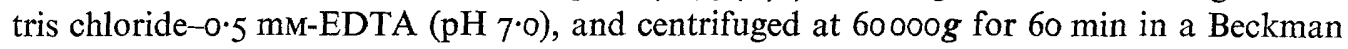
SW 25.1 rotor. Gradients were fractionated into $\mathrm{I} \mathrm{ml}$ samples on an ISCO fractionator scanning at $254 \mathrm{~nm}$. The extinction recorded was predominantly due to light scattering.

\section{Determination of radioactivity}

Bovine serum albumin $(5 \mathrm{mg})$ was added to gradient fractions followed by $2 \mathrm{ml}$ cold $0.5 \mathrm{M}$-trichloroacetic acid-7 mM-leucine. Precipitated protein was washed once with trichloroacetic acid-leucine, and heated at $85^{\circ} \mathrm{C}$ for $\mathrm{I} 5 \mathrm{~min}$ in the same solution. The precipitate was washed twice with water, and resuspended in water. Portions were transferred to vials containing dioxane-naphthalene-PPO (Beckman) and assayed for radioactivity with correc- 
tion for quenching. Promitochondria and cytosol fractions were prepared for radioassay in the same way, except that serum albumin was not added.

\section{Incorporation of labelled amino acid into cell protein}

Samples containing approximately ro $\mathrm{mg}$ dry wt organisms suspended and pre-incubated in phosphate-galactose as described above, but without cycloheximide, were incubated for o to Io min with $2 \mu \mathrm{Ci} \mathrm{L}-\left[4,5{ }^{3} \mathrm{H}\right]$ leucine $(0.5 \mathrm{Ci} / \mathrm{mol})$. Samples were removed at 2 min intervals and pipetted into 2 volumes of trichloracetic acid-leucine, heated at $85^{\circ} \mathrm{C}$ for $15 \mathrm{~min}$, washed again with trichloroacetic acid-leucine, then with acetone and resuspended in ethanolether $(2: \mathrm{I}, \mathrm{v} / \mathrm{v})$. The organisms were heated for a further $\mathrm{I} 5 \mathrm{~min}$ at $65{ }^{\circ} \mathrm{C}$, washed with ethyl ether, dried, resuspended in water, a sample taken for dry weight estimation, and a further sample assayed for radioactivity as described above.

\section{Extraction of lipids}

Fatty acids and sterol were extracted and determined as described previously (Gordon \& Stewart, 1971).

\section{Extraction and fractionation of $R N A$}

RNA was extracted from promitochondria and the postmitochondrial supernatant of glutaraldehyde-fixed cells as described by Yu, Poulson \& Stewart (I97I), except that the fixation period for lipid-depleted cells was decreased to Io min at $0{ }^{\circ} \mathrm{C}$.

\section{Preparation of ribosome/polysome fractions}

Organisms were suspended in AMT (I00 mM-ammonium chloride, Io mM-magnesium chloride, Io mM-tris chloride; $\mathrm{pH} 7 \cdot 6$ ), containing Io mM-mercaptoethanol, and broken for I $5 \mathrm{~s}$ at low temperature in a Braun MSK homogenizer. This method was found to be equal or superior to methods involving alumina grinding, or freezing and grinding in liquid nitrogen, as judged by the proportion of ribosomes recovered as polysomes. After decanting, the beads were washed with AMT-mercaptoethanol and the pooled homogenate and washings were centrifuged at $25000 \mathrm{~g}$ for $20 \mathrm{~min}$. Ribosomes were collected from the supernatant by centrifuging at $150000 \mathrm{~g}$ for $60 \mathrm{~min}$ in a Beckman 50 rotor. The loosely packed portion of the pellet was washed off and the firm, gelatinous pellet was gently resuspended in AMTmercaptoethanol.

Soluble factors were prepared by adjusting the $\mathrm{pH}$ value of the postribosomal supernatant to $5^{\circ} 0$ with acetic acid. After $30 \mathrm{~min}$ at $0^{\circ} \mathrm{C}$, the precipitate was sedimented (I0000 $\mathrm{g}, 5 \mathrm{~min}$ ) and redissolved in AMT buffer. This fraction was most active when the cell homogenate was kept as concentrated as possible.

\section{Measurement of amino acid incorporation by ribosomal systems}

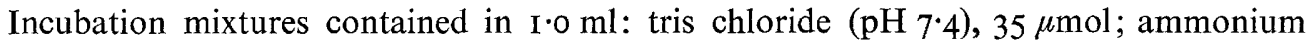
chloride, $\mathrm{I} 40 \mu \mathrm{mol}$; magnesium acetate, $8.5 \mu \mathrm{mol}$; mercaptoethanol, $2 \mu \mathrm{mol}$; dipotassium ATP, I $\mu \mathrm{mol}$; potassium phosphoenolpyruvate, $5 \mu \mathrm{mol}$; pyruvate kinase (Sigma), $30 \mu \mathrm{g}$ ( $5 \mathrm{U})$; RNA (prepared from the postmitochondrial supernatant as described above), $50 \mu \mathrm{g} ; \mathrm{L}-\left[2{ }^{14} \mathrm{C}\right]$ leucine $(40 \mathrm{Ci} / \mathrm{mol}), 0 \cdot 2 \mu \mathrm{Ci}$; and approximately $\mathrm{I} \mathrm{mg}$ each of ribosomal and $\mathrm{pH} 5$-fraction protein. Incorporation was linear for at least $20 \mathrm{~min}$ at $30{ }^{\circ} \mathrm{C}$, and at this time the reaction was stopped by adding $5 \mathrm{ml}$ of $7.5 \%(\mathrm{w} / \mathrm{v})$ trichloroacetic acid in $33 \%(\mathrm{v} / \mathrm{v})$ ethanol, followed by $2 \mathrm{mg}$ bovine serum albumin. Precipitates were processed as described for gradient fractions prior to determination of radioactivity. 


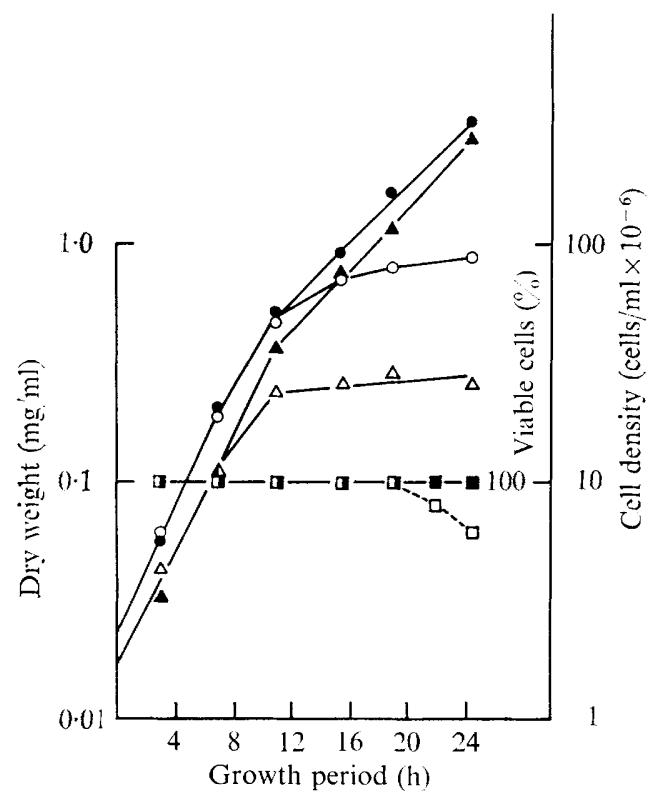

Fig. I

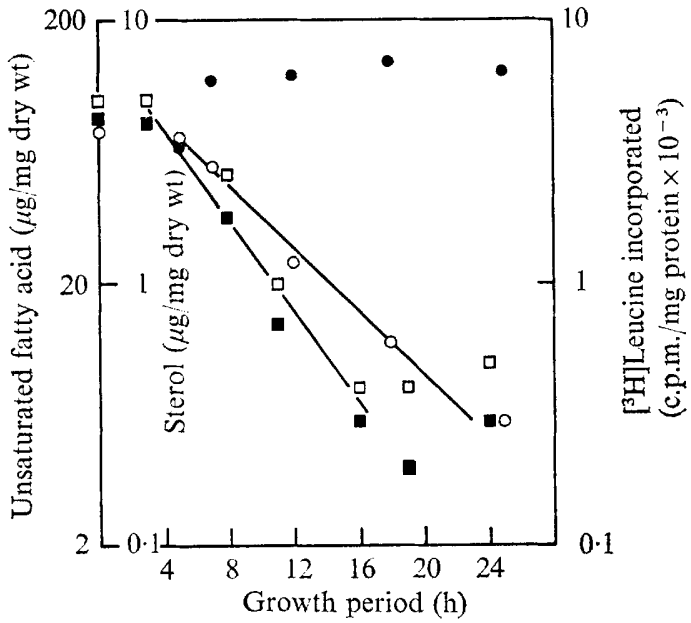

Fig. 2

Fig. I. Growth and viability in supplemented (Tween 80 plus ergosterol) and non-supplemented cultures of Saccharomyces cerevisiae. Organisms were grown anaerobically from an aerobically grown inoculum. At intervals samples were removed and the yeast number and dry weight measured. Dry weight was measured by light-scattering at $640 \mathrm{~nm}$. Viability was measured using buffered methylene blue as described by Gurr (1965). Supplemented cultures: - - - dry weight; $-\mathbf{A}-\mathbf{\Delta}-\mathbf{\Delta}-$, cells $/ \mathrm{ml}$; - $\mathbf{\square}-\mathbf{\square}-$, \% viable organisms. Non-supplemented cultures: $-\mathrm{O}-\mathrm{O}-\mathrm{O}-$, dry weight; $-\triangle-\triangle-\triangle-$, cells $/ \mathrm{ml} ;-\square-\square-\square-$, \% viable organisms.

Fig. 2. Dilution of lipid during anaerobic growth, and incorporation of $\mathrm{L}-\left[4,5-{ }^{3} \mathrm{H}\right]$ leucine into protein of Saccharomyces cerevisiae. Organisms were grown as described in Fig. I ; at intervals samples were removed for analysis of unsaturated fatty acids and sterol and for the capacity to incorporate labelled leucine into cell protein. Unsaturated fatty acid $(-\mathbf{D}-\mathbf{n}-\mathbf{\square})$ and ergosterol (一 $\square-\square-\square-$ ) content of organism from non-supplemented cultures. Incorporation of ${ }^{3} \mathrm{H}$-leucine into protein by organisms from non-supplemented cultures (-O-O-O-), and from supplemented cultures ( $(\mathbf{)}$ ). The unsaturated fatty acid content of organisms from supplemented cultures was similar to that of aerobic organisms; the sterol content of supplemented cells was about onehalf that of aerobic organisms (cf. Gordon \& Stewart, I97I).

\section{Assay procedures}

Protein was assayed by the method of Lowry, Rosebrough, Farr \& Randall (I95I), RNA by the method of Kerr \& Seradairian (1945), and ATPase (adenosine triphosphate phosphohydrolase, EC. 3.6.1.4) by the method of Kovac, Bednarova \& Grekshak (1968).

\section{RESULTS}

\section{Growth physiology of anaerobic cultures}

Growth curves for lipid-depleted and lipid-supplemented anaerobic cultures are shown in Fig. I. Both cultures grew at the same rate initially, but division of yeasts in media lacking Tween 80 and ergosterol slowed considerably about I I $h$ after inoculation. This coincided with depletion of unsaturated fatty acids to less that $20 \mu \mathrm{g} / \mathrm{mg}$ dry wt (Fig. 2) compared with about $80 \mu \mathrm{g} / \mathrm{mg}$ found in aerobically grown cells. Reduction of sterol content of the cells 


\section{Table I. Incorporation of $\left[{ }^{3} \mathrm{H}\right]$ leucine into protein of organisms and of promitochondria and cytosol}

Organisms were grown aerobically on non-supplemented media containing I \% galactose to late log phase, or anaerobically on supplemented (Tween 80 plus ergosterol) or non-supplemented media as indicated for $18 \mathrm{~h}$. They were harvested in the presence or absence of cycloheximide ( $10 \mu \mathrm{g} / \mathrm{ml})$ then incubated anaerobically with $\mathrm{L}-\left[4,5^{-}{ }^{3} \mathrm{H}\right]$ leucine in the presence or absence of cycloheximide $(25 \mu \mathrm{g} / \mathrm{ml})$ as appropriate. Promitochondria and cytosol fractions were prepared from the organisms, and incorporation into protein measured in these and in the cells.

ATPase was measured in cell-free homogenates and in the washed promitochondrial fractions. Figures in parentheses indicate recovery $(\%)$ from homogenates into the promitochondrial fractions. The promitochondrial activity was inhibited more than $90 \%$ by $50 \mu \mathrm{g}$ oligomycin/mg protein.

\begin{tabular}{|c|c|c|c|c|c|c|c|}
\hline \multirow[b]{2}{*}{$\begin{array}{c}\text { Cell type } \\
\text { and antibiotic } \\
\text { present during } \\
\text { labelling }\end{array}$} & \multirow[b]{2}{*}{$\begin{array}{c}\text { ATPase } \\
\text { activity } \\
\text { of MT* } \\
\text { ( } \mu \text { mol phosphate } / \\
\text { min/mg protein) }\end{array}$} & \multicolumn{3}{|c|}{$\begin{array}{c}\text { Incorporation in absence } \\
\text { of cycloheximide }\end{array}$} & \multicolumn{3}{|c|}{$\begin{array}{l}\text { Incorporation in presence } \\
\text { of cycloheximide }\end{array}$} \\
\hline & & $\overbrace{\text { (c. } T^{*}}^{\mathrm{MT}^{*}}$ & $\begin{array}{l}\text { SOL } † \\
\text { a. } / \mathrm{mg} \\
\text { tein) }\end{array}$ & $\begin{array}{l}\text { Cells } \\
\text { (c.p.m./mg } \\
\text { dry wt) }\end{array}$ & $\begin{array}{r}\mathrm{MT}^{*} \\
\text { (c.p } \\
\mathrm{pr}\end{array}$ & $\begin{array}{l}\text { SOL }+ \\
\text { /mg } \\
\text { in) }\end{array}$ & $\begin{array}{l}\text { Cells } \\
\text { (c.p.m.l } \\
\text { mg dry } \\
\text { wt) }\end{array}$ \\
\hline be & $\mathrm{I} \cdot 06(8 \mathrm{I})$ & 102000 & 61500 & 31600 & 9450 & I32. & 520 \\
\hline $\begin{array}{l}\text { obe }+ \text { ER } \ddagger \\
\text { obe + EB } \ddagger\end{array}$ & - & $\begin{array}{c}75100 \\
-\end{array}$ & 55300 & 28300 & $\begin{array}{r}567 \\
2260\end{array}$ & $\begin{array}{r}55 \\
119\end{array}$ & $\begin{array}{r}45 \\
\text { I } 59\end{array}$ \\
\hline $\begin{array}{l}\text { erobe, lipid } \\
\text { plemented }\end{array}$ & $0.71(60)$ & 42100 & 36300 & 17300 & 2280 & 182 & I 81 \\
\hline $\begin{array}{l}\text { laerobe, lipid } \\
\text { Ipplemented + ER } \ddagger\end{array}$ & 一 & - & - & 一 & I 40 & I4I & 43 \\
\hline $\begin{array}{l}\text { laerobe, lipid depleted } \\
\text { laerobe, lipid } \\
\text { epleted +ER } \$\end{array}$ & $\frac{0.30(56)}{-}$ & 320 & $\stackrel{1040}{-}$ & $\stackrel{630}{-}$ & $\begin{array}{l}72 \\
30\end{array}$ & $\begin{array}{r}112 \\
52\end{array}$ & $\begin{array}{l}37 \\
32\end{array}$ \\
\hline
\end{tabular}

followed a similar dilution pattern. In the $\mathrm{I} 2$ to $\mathrm{I} 4 \mathrm{~h}$ after cell division ceased, cell mass approximately doubled (Fig. I).

By comparison, lipid-supplemented yeasts divided and grew continuously over the period observed, though not logarithmically (Fig. I). There were only small changes in fatty acid levels (total and unsaturated) after growth in this medium, although there was a decline in sterol content to about one-half that found in aerobic cells (Gordon \& Stewart, 197I). The latter effect was not caused by insufficiency of sterol in the medium, and presumably reflected a diminished requirement for sterol under anaerobic conditions.

The viability of the two kinds of cultures, as shown by the capacity of the cells to exclude methylene blue (Gurr, 1965), was different to the extent that, shortly after yeast mass ceased to increase in lipid-depleted cultures, yeast viability began to fall, whereas in supplemented cultures very few non-viable cells were detected during the period of the experiment (Fig. I). After about $24 \mathrm{~h}$ lipid-depleted cultures contained up to $20 \%$ non-viable yeasts.

The capacity of cells to incorporate labelled leucine into protein was also measured throughout the growth cycle in the two types of cultures (Fig. 2). In supplemented cultures, protein synthesis continued at a high, fairly constant rate; in depleted yeasts there was a decline in this activity which was slightly slower than the dilution rate of lipids in these yeasts. The increase in mean cell mass after cell division ceased in depleted cultures was thus similar to the unbalanced growth seen in bacteria when protein synthesis is inhibited (Shockman, 1965). 




Fig. 3

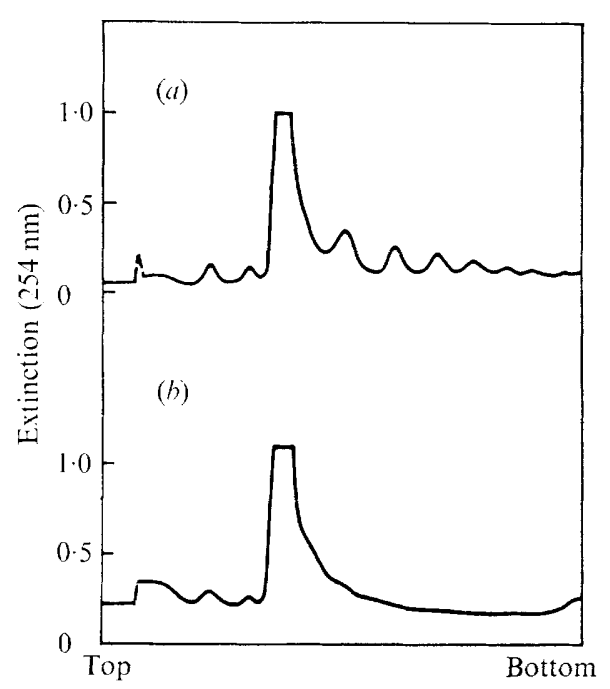

Fig. 4

Fig. 3. Sucrose density gradient analysis of label associated with promitochondria from (a) lipidsupplemented and $(b)$ lipid-depleted organisms labelled in situ. Organisms were grown for $\mathbf{I} \mathrm{h}$ under anaerobic conditions with or without lipid supplement. After chilling and harvesting in the presence of cycloheximide, they were pulse-labelled in the presence of cycloheximide with $\mathrm{L}-\left[4,5{ }^{3} \mathrm{H}\right] \mathrm{leucine}$. Promitochondria were prepared and loaded on to gradients of 30 to $70 \%$ sucrose-ro mM-trischloride-0.5 mM-EDTA $(\mathrm{pH} \mathrm{7.0)}$ ) and centrifuged for $60 \mathrm{~min}$ at $63000 \mathrm{~g}$ (Beckman SW $25 \cdot \mathrm{I}$ ). Fractions $(\mathrm{I} \cdot 0 \mathrm{ml})$ were collected from the $50 \%$ sucrose region upwards, and assayed for radioactivity. $\ldots .-, E_{254}$ trace from ISCO fractionator; $-\mathrm{O}-\mathrm{O}-\mathrm{O}-$, c.p.m./fraction. Figures in parentheses indicate estimated particle densities. -ER and +ER indicate that erythromycin $(5 \mathrm{mg} / \mathrm{ml})$ was present during pulse-labelling of the cells.

Fig. 4. Ribosome/polysome complement of depleted and supplemented cells. Ribosome/polysome fractions were prepared from cells grown anaerobically for $18 \mathrm{hr}$ with and without lipid supplements. After centrifugation of these preparations for $2.5 \mathrm{~h}$ at $63000 \mathrm{~g}$ on io to $30 \%$ sucrose gradients ( $\mathrm{Yu}$ et al. 1972), the gradients were passed through an ISCO fractionator scanning at $254 \mathrm{~nm}$. (a) Untreated preparation from lipid-depleted cells. (b) Preparation from lipid-depleted cells treated with ribonuclease (Sigma, Type X-A, $50 \mu \mathrm{g} / \mathrm{ml}$ ) just prior to centrifugation. Preparations from lipid-supplemented yeast were indistinguishable on sucrose gradients from those from depleted yeast.

\section{Measurement of mitochondrial and cytoplasmic protein synthesis}

Aerobic yeasts incorporated label extensively into both mitochondrial and soluble cytoplasmic protein (Table I). A preferential labelling of mitochondrial protein was evident, similar to that described by Schatz \& Saltzgaber (1969) and Schweyen \& Kaudewitz (1970). In the absence of cycloheximide, erythromycin inhibited labelling of mitochondrial protein by about $25 \%$, and of soluble protein by about $10 \%$. When labelling was carried out in the presence of cycloheximide, to inhibit the contribution of cytoplasmic synthesis to soluble and mitochondrial protein, a very high relative labelling of mitochondrial protein was seen. This preferential labelling of mitochondrial protein was inhibited more than $90 \%$ by erythromycin. Ethidium bromide also inhibited mitochondrial protein synthesis.

Lipid-supplemented anaerobic yeast also incorporated label actively in the absence of cycloheximide (Table I). However, the labelling of protein in lipid-depleted organisms was low regardless of the presence or absence of cycloheximide. The labelling of cell protein paralleled the labelling of cytosol protein, and thus provided a measure of activity of the cytoplasmic ribosomal system in situ. This was a consequence of the fact that the mitochon- 


\section{Table 2. Effect of yeast lipid status on amino acid incorporation by isolated cytoplasmic ribosomes}

Yeast was grown for $17 . \mathrm{h}$ anaerobically, or for $\mathrm{I} 5 \mathrm{~h}$ aerobically, and ribosome and $\mathrm{pH} 5$-fractions prepared.

The complete system is described in detail in Methods. Cycloheximide was added as indicated at $25 \mu \mathrm{g} / \mathrm{ml}$.



Aerobe

Anaerobe, lipid-supplemented

Anaerobe, lipid-depleted

I $\cdot 4$

O.I

$0 \cdot 1$

0.4

Table 3. Protein synthesis by isolated ribosomal systems: recombination of ribosomal and soluble factors from lipid-depleted and lipid-supplemented yeasts

Yeast was grown anaerobically for $\mathrm{I} 7 \mathrm{~h}$, and ribosome and $\mathrm{pH}$-fractions prepared.

The complete system is described in the text. Minus RNA: high molecular weight RNA was deleted from, the assay system. Cycloheximide $(25 \mu \mathrm{g} / \mathrm{ml})$ was added as indicated.

\begin{tabular}{|c|c|c|c|c|}
\hline \multicolumn{2}{|c|}{ Source of } & \multicolumn{3}{|c|}{ Amino acid incorporating system } \\
\hline Ribosomes & $\mathrm{pH} 5$ fraction & Complete & minus RNA & Plus cycloheximide \\
\hline & \multicolumn{4}{|c|}{ (pmol $\left[{ }^{14} \mathrm{C}\right]$ leucine incorporated/20 $\mathrm{min} / \mathrm{mg}$ ribosomal protein) } \\
\hline SUP* & SUP & $24 \cdot I$ & $5 \cdot I$ & $3 \cdot 9$ \\
\hline DEP* & DEP & 0.7 & 0.8 & 0.6 \\
\hline SUP & DEP & $6 \cdot 8$ & $I \cdot 6$ & $I \cdot 0$ \\
\hline DEP & SUP & $\mathrm{I} \cdot 8$ & $I \cdot 3$ & $\mathrm{I} \cdot \mathrm{O}$ \\
\hline
\end{tabular}

* Ribosomes of $\mathrm{pH} 5$ fraction obtained from lipid-supplemented (SUP) or lipid-depleted (DEP) yeast respectively.

drial system accounted for the synthesis of $10 \%$ or less of mitochondrial protein, or less than $2 \%$ of the whole cell protein; the remainder in each case was apparently contributed by the cytoplasmic ribosomes.

Promitochondria prepared from lipid-supplemented anaerobes accounted for more than half of the oligomycin-sensitive ATPase in homogenates (Table I). In organisms pulselabelled with $\left[{ }^{3} \mathrm{H}\right]$ leucine in the presence of cycloheximide, there was substantial preferential labelling of the promitochondria, and this labelling was very sensitive to inhibition by erythromycin. The label was found to be associated with the less dense (I·I5) and smaller of the two bands recovered from the gradients (Fig. $3 a$ ).

Promitochondria from lipid-depleted anaerobes accounted for a proportion of the ATPase similar to that found in supplemented cells (Table I) but contained only trace amounts of isotope after pulse-labelling in the presence of cycloheximide (Fig. $3 b$ ). There was no significant effect of erythromycin on this labelling.

\section{Effect of lipid-depletion on protein synthesis in vitro.}

In order to define more precisely the reasons for loss of protein synthesis in depleted cells, ribosome and supernatant fractions were prepared from aerobic and from anaerobic lipiddepleted and lipid-supplemented cells, and the ability of the ribosomal systems to incor- 
porate amino acids into protein measured. Systems reconstituted from aerobically grown yeast or from yeast grown anaerobically with lipid supplements were both active: these were sensitive to cycloheximide, dependent on an energy source and on the soluble $(\mathrm{pH} 5)$ fraction (Table 2). Incorporation was linear for at least $20 \mathrm{~min}$. The reconstituted system from yeast grown anaerobically without lipids on the other hand had little or no activity.

Comparison of the homologous and heterologous ribosomal and soluble fractions from lipid-depleted and lipid-supplemented cells (Table 3 ) indicated that the loss of activity was primarily an effect on the ribosomes, rather than on the soluble fraction, because considerable activity was obtained in mixtures of the soluble fraction from depleted yeast with ribosomes from supplemented yeast, provided that high molecular weight RNA was present. There was no significant stimulation by RNA when ribosomes from depleted yeast were used, and this would suggest that these cells are not inactive simply because of lack of messenger RNA. This is supported by analysis of the ribosome fractions of linear sucrose density gradients (Fig. 4). Ribosome preparations from yeast grown anaerobically for $\mathrm{I} 8 \mathrm{~h}$ in the presence or absence of lipid supplements contained very similar proportions of ribosomes and polysomes. Though not shown, aerobic organisms cultured to late logarithmic phase were similar in this respect to organisms cultured anaerobically. Amino acid incorporation was also measured in preparations of the membrane fraction sedimenting between $9000 \mathrm{~g}$ and $25000 \mathrm{~g}$ from anaerobic yeast. The activity of this fraction was not significant in either preparation.

\section{$R N A$ content and species of anaerobic organism}

A comparison of the total complement of ribosomes, as ribosomal RNA and tRNA, was made by estimating the total RNA in cell homogenates, followed by extraction and electrophoretic analysis on polyacrylamide gel (Loening, 1969). There was no obvious difference in the amount of RNA, in the number of species of RNA, or the relative proportions of these species, with the possible exception of slightly smaller amounts of $4 \mathrm{~S}$ RNA in depleted cells (Fig. 5). There was no significant degradation of the high molecular weight RNA. These results are consistent with those obtained from the analysis of the ribosomal species on sucrose density-gradients, discussed above, and suggest that no major quantitative or qualitative change in RNA content was brought about by lipid depletion.

\section{RNA from promitochondria}

When promitochondria were isolated from anaerobic organisms prefixed with glutaraldehyde ( $\mathrm{Yu}$ et al. $197 \mathrm{I}$ ), only promitochondrial fractions isolated from lipid-supplemented yeast contained RNA of mitochondrial origin (Fig. 6b). Promitochondria from lipiddepleted anaerobes contained only contaminating cytoplasmic species (Fig. 6c). The amount of mitochondrial RNA was somewhat smaller, compared with contaminating cytoplasmic RNA, in the supplemented anaerobes than could be recovered from mitochondria prepared in the same way from aerobic cells (Fig. 6a).

\section{Re-establishment of protein synthesis in anaerobic lipid-depleted organisms by aeration}

The ready reversibility of the 'quiescent' state induced in cells by depletion of essential lipids could be demonstrated by exposure of these organisms to air for short periods. After aeration for $2 \mathrm{~h}$, without significant growth in the cultures, cytoplasmic and mitochondrial protein synthesis as measured in situ were reinstated (Table 4). Re-activation of protein synthesis in depleted organisms was also achieved when organisms were aerated after 


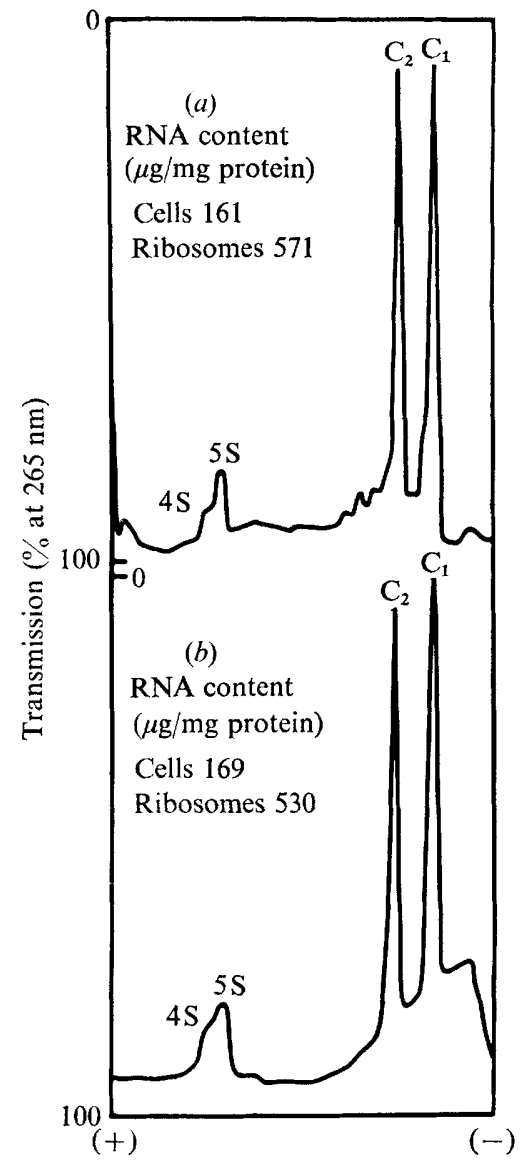

Fig. 5

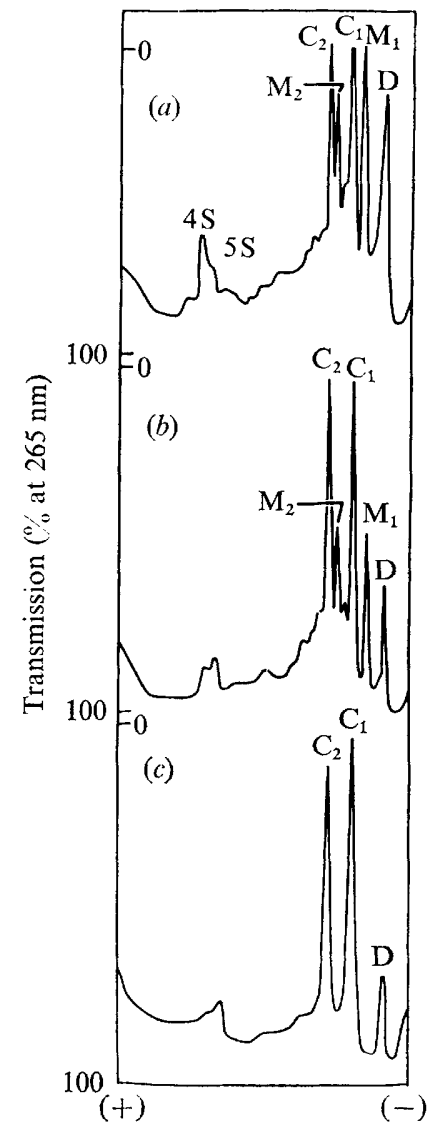

Fig. 6

Fig. 5. RNA species present in anaerobically cultured yeast. Yeast grown as described in Fig. 4 was fixed with glutaraldehyde for $10 \mathrm{~min}$ at $0^{\circ} \mathrm{C}$, and RNA was extracted from the cytoplasmic ribosomal fraction and subjected to gel electrophoresis for $2 \cdot 5 \mathrm{~h}$ at $22{ }^{\circ} \mathrm{C}$ (Yu et al. 1972). Gels were washed in water for $\mathrm{I} \mathrm{h}$ then scanned at $265 \mathrm{~nm}$ in a Joyce-Loebl Chromoscan. The RNA contents of the homogenates and ribosome fractions were determined by the orcinol method of Kerr \& Seradairian (1945). Cytoplasmic ribosomal species of RNA (25S, I8S) are denoted $C_{1}$ and $\mathrm{C}_{2}$ respectively. (a) Lipid-depleted cells. (b) Lipid-supplemented cells.

Fig. 6. RNA from (pro)mitochondria. Yeast grown anaerobically, as described in Fig. 4, and yeast grown aerobically to early stationary phase on galactose were fixed with glutaraldehyde, disrupted mechanically, and promitochondria prepared, purified and extracted for RNA as described by Yu et al. (1972). The RNA was subjected to gel electrophoresis for $2 \mathrm{~h}$ at $22{ }^{\circ} \mathrm{C}$. Gels were washed in water for $\mathrm{I} h$ then scanned at $265 \mathrm{~nm}$ in a Joyce-Loebl Chromoscan. $C_{1}$ and $C_{2}$ indicate respectively the large and small RNA species $(25 \mathrm{~S}, \mathrm{I} 8 \mathrm{~S})$ of cytoplasmic ribosomes, and $\mathbf{M}_{1}$ and $\mathbf{M}_{2}$ the corresponding species from promitochondria. D indicates DNA. (a) Aerobically grown yeast. (b) Anaerobic, lipid-supplemented yeast. (c) Anaerobic, lipid-depleted yeast.

resuspension in spent anaerobic media (i.e. media from which they had been harvested), or in phosphate-buffered galactose solution, indicating that the effect was not due to culture step-up.

Associated with this re-activation of protein synthesis was a rapid increase in amount of unsaturated fatty acid and sterol (Table 4). Though the proportion of fatty acids accounted for as unsaturated species after aeration for $2 \mathrm{~h}$ was similar to that found in aerobic cells, 


\section{Table 4. Re-establishment of mitochondrial and cytoplasmic protein synthesis during aeration of lipid-depleted anaerobes}

Organisms were grown anaerobically without lipid supplements for $18 \mathrm{~h}$. After chilling and harvesting (no cycloheximide added) a sample was removed, cycloheximide $(25 \mu \mathrm{g} / \mathrm{ml}$ ) added, and labelling carried out with $\left[{ }^{3} \mathrm{H}\right]$ leucine to measure the activity of the promitochondrial system. A sample of anaerobic organisms was labelled separately in the absence of cycloheximide to estimate whole organism incorporation.

The remaining anaerobic organisms were resuspended in fresh media plus $\mathrm{I} \%$ galactose at $5 \cdot 0 \mathrm{mg}$ dry $\mathrm{wt} / \mathrm{ml}$ and aerated for 2 or $4 \mathrm{~h}$ in the presence of the inhibitors indicated. Some flasks were flushed with oxygen-free nitrogen for similar periods. At the end of this time, organisms were harvested and promitochondrial and whole organism labelling determined as described for anaerobic organisms.

Samples were also taken and unsaturated fatty acids and ergosterol extracted and estimated. Figures in parentheses indicate percentage of total fatty acids accounted for as unsaturated fatty acids.

\begin{tabular}{|c|c|c|c|c|c|c|}
\hline \multirow[b]{2}{*}{ Aeration conditions } & \multirow{2}{*}{\multicolumn{2}{|c|}{$\begin{array}{l}\text { Cell density } \\
\text { in aeration } \\
\text { suspension } \\
(\mathrm{mg} \text { dry } w \mathrm{t} / \mathrm{ml})\end{array}$}} & \multicolumn{2}{|c|}{$\begin{array}{l}\text { Amino acid } \\
\text { incorporation by }\end{array}$} & \multicolumn{2}{|c|}{ Cell lipid } \\
\hline & & & $\begin{array}{l}\text { Mitochondria } \\
\text { (c.p.m./mg } \\
\text { protein) }\end{array}$ & $\begin{array}{l}\text { Organism } \\
\text { (c.p.m./mg } \\
\text { dry wt) }\end{array}$ & \multicolumn{2}{|c|}{$\begin{array}{c}\text { Unsaturated } \\
\text { fatty acid } \\
(\mathrm{mg} / \mathrm{g} \text { dry } \mathrm{wt})\end{array}$} \\
\hline Nil (anaerobe) & & - & 1050 & 1070 & $0.2 \mathrm{I}$ & $5 \cdot 3$ (19) \\
\hline Air, 2 h & & 一 & I 2900 & - & $2 \cdot 7$ & $54(70)$ \\
\hline Air, $4 \mathrm{~h}$ & & $5^{\circ} 0$ & I 8860 & I 3200 & $4 \cdot 2$ & $7 \mathrm{I}(77)$ \\
\hline Nitrogen, $2 \mathrm{~h}$ & & - & I 440 & - & 0.22 & $7 \cdot 2(17)$ \\
\hline Nitrogen, $4 \mathrm{~h}$ & & $4 \cdot 9$ & 890 & 720 & 0.44 & $10 \cdot 0(20)$ \\
\hline $\begin{array}{l}\text { Air, } 4 \mathrm{~h} \text { + erythromycin } \\
(5 \mathrm{mg} / \mathrm{ml})\end{array}$ & & $5 \cdot 3$ & I 930 & 12900 & $5 \cdot I$ & $80(76)$ \\
\hline $\begin{array}{l}\text { Air, } 4 \mathrm{~h}+\text { cycloheximide } \\
(25 \mu \mathrm{g} / \mathrm{ml})\end{array}$ & & $5 \cdot I$ & 420 & 320 & $\mathrm{I} \cdot 4$ & $36(58)$ \\
\hline $\begin{array}{l}\text { Air, } 4 \mathrm{~h}+\text { ethidium brot } \\
(50 \mu \mathrm{g} / \mathrm{ml})\end{array}$ & nide & $5 \cdot 0$ & I 590 & I 3200 & $5 \cdot 8$ & $76(77)$ \\
\hline
\end{tabular}

there was still substantially less total unsaturated fatty acid in these cells compared with aerobically cultured cells.

When depleted organisms were treated in identical fashion to those in the aeration experiments, except that nitrogen replaced air as the gas phase, synthesis of unsaturated fatty acids or sterol was inhibited almost completely. Likewise, as long as air was rigorously excluded, there was no increase in the activity of the protein-synthesizing systems (Table 4).

The presence of cycloheximide during aeration completely inhibited development of activity of the mitochondrial protein-synthesizing system (Table 4). Products of the cytoplasmic system thus appear to be required, and these would include ribosomal proteins as suggested by Davey, Yu \& Linnane (1969) and by Kuntzel (1969). Cycloheximide also inhibited synthesis of lipids during aeration, as reported previously (Gordon \& Stewart, 1971).

Erythromycin and ethidium bromide also inhibited development of activity of the mitochondrial system, while having little if any effect on development of the cytoplasmic system. However, these results need to be interpreted with caution because, though the organisms were extensively washed after the aeration phase of the experiment, it is possible that incomplete removal of these antibiotics before measurement of mitochondrial protein synthesis could account for the results seen (cf. Table I). Neither of these antibiotics affected synthesis of sterols or unsaturated fatty acids. 


\section{DISCUSSION}

A satisfactory explanation for the loss of protein synthesis on cytoplasmic ribosomes as depletion of lipids occurs is not immediately available. Lucas, Schuurs and Simpson (1964) reported that the activity of the cytoplasmic ribosomal system of yeast declines as organisms pass into late-logarithmic phase. This decline in activity is accompanied by a precipitous decline in the amount of RNA in the cell, and with cessation of synthesis of RNA. In lipiddepleted organisms, loss of activity in the cytoplasm seems to be primarily caused by a defect in the ribosomes, but is not caused by loss of integrity of ribosomal or associated RNA, nor by decrease in the ribosome/polysome complement. Furthermore, the loss of ability to synthesize protein is rapidly reversed by exposure of organisms to oxygen in the absence of significant growth. Synthesis of unsaturated fatty acids and sterol proceeds rapidly under these conditions. The effect of lipid depletion on protein synthesis in thus apparently not a consequence of the cessation of growth and division of organisms as such, but of their lipid status.

The activity of membrane-associated protein synthesis is very low in both types of anaerobic organism, and this, together with electron-micrograph evidence indicating a paucity of membrane-associated ribosomes in yeast cells (Matile, Moor \& Robinow, I969), suggests that, quantitatively at least, membrane-associated protein synthesis is not well developed in this organism. An explanation of the tight control of protein synthesis by lipid level might lie in a more subtle effect of lipid depletion, for instance on the synthesis of regulatory species of RNA, such as specific types of RNA or of modulating tRNA.

While cytoplasmic RNA appears to be stable in lipid-depleted organisms, mitochondrial RNA clearly is susceptible to the altered lipid status of the organism and organelle. Its absence could conceivably be due to loss during preparation and purification of the mitochondrial fraction, particularly if the altered lipid composition results in greater fragility of the organelle. Alternatively, the absence of RNA from depleted mitochondria may be a consequence of either membrane-dependent regulation of RNA synthesis (Forrester, Watson \& Linnane, 197I), or rapid turnover in the absence of synthesis (Attardi et al. 1971).

Aeration of lipid-depleted organisms resulted in a rapid reversal of the effects of lipid depletion on mitochondrial and cytoplasmic protein synthesis. Relevant to the findings of Vary et al. (1970) is the fact that significant mitochondrial activity was not seen after aeration in the presence of erythromycin, whereas development of activity of the cytoplasmic system was apparently unaffected. Also, complete development may take $4 \mathrm{~h}$ or more, so that interference with the activity of the mitochondrial system up to this time may cause incomplete or altered subsequent development of the organelle (Vary et al. 1970).

Note added in proof. Groot, Rouslin \& Schatz, 1972 (Journal of Biological Chemistry 247, I 735-I 742) have recently reported that erythromycin inhibits incorporation of leucine into protein in yeast cells by inhibiting uptake of the amino acid. The erythromycin glucoheptonate used in the present study had little effect on amino acid incorporation into cytosol protein (Table $\mathrm{I}$ ) and thus is an acceptable inhibitor of mitochondrial protein synthesis measured in situ with this organism.

We thank Miss Dagmar Albrecht for technical assistance, Dr R. S. T. Yu for advice on extraction of RNA, and Professor D. J. Carr for his interest and encouragement.

\section{REFERENCES}

Attardi, G., Aloni, Y., Attardi, B., Lederman, M., Ojala, D., Pica-Mattoccia, L. \& Storrie, B. (i97I). Properties of mitochondrial RNA in HeLa cells. In Autonomy and Biogenesis of Mitochondria and Chloroplasts, pp. 293-310. Edited by N. K. Boardman, A. W. Linnane \& R. M. Smillie. Amsterdam: North-Holland Publishing Co. 
Cundliffe, E. (1970). Intracellular distribution of ribosomes and polyribosomes in Bacillus megaterium. Journal of Molecular Biology 52, 467-48I.

Davey, P., YU, R. S. T. \& Linnane, A. W. (I969). The intracellular site of formation of the mitochondrial protein synthetic system. Biochemical and Biophysical Research Communications 36, 30-34.

Forrester, I. T., Watson, K. \& Linnane, A. W. (I97I). Mitochondrial membrane organization, a determinant of mitochondrial ribosomal RNA synthesis. Biochemical and Biophysical Research Communications 43, 409-4I5.

Gordon, P. A. \& Stewart, P. R. (197I). The effect of antibiotics on lipid synthesis during respiratory development in Saccharomyces cerevisiae. Microbios 4, I I 5-132.

Gordon, P. A., Stewart, P. R. \& Clark-Walker, G. D. (I97I). Fatty acid and sterol composition of Mucor genevensis in relation to dimorphism and anaerobic growth. Journal of Bacteriology 107, I I 4-I 20.

Gurr, E. (1965). The Rational Use of Dyes in Biology, pp. 213-214. London: Leonard Hill.

Hendler, R. W. (1965). Importance of membranes in protein synthesis. Nature, London 207, $1053-1054$.

Jollow, D., Kellerman, G. M. \& Linnane, A. W. (I968). The biogenesis of mitochondria. III. The lipid composition of aerobically and anaerobically grown Saccharomyces cerevisiae related to the membrane systems of the cells. Journal of Cell Biology 37, 221-230.

Kerr, S. E. \& Seraidarian, K. (I945). The separation of purine nucleosides from free purines and the determination of the purines and ribose in these reactions. Journal of Biological Chemistry $\mathbf{I}_{59}, 2 \mathrm{I}$ I-225.

Kovac, L., Bednarova, H. \& GrekshaK, M. (1968). Oxidative phosphorylation in yeast. I. Isolation and properties of phosphorylating mitochondria from stationary-phase cells. Biochimica et biophysica acta I53, 32-42.

Kuntzel, H. (1969). Proteins of mitochondrial and cytoplasmic ribosomes from Neurospora crassa. Nature, London 222, $142-146$.

LoENING, U. E. (I969). The determination of the molecular weight of ribonucleic acid by polyacrylamide-gel electrophoresis. Biochemical Journal r13, I3I-I38.

Lowry, O. H., Rosebrough, W. J., Farr, A. L. \& Randall, R. J. (I95I). Protein measurement with the Folin phenol reagent. Journal of Biological Chemistry r93, 265-275.

Lucas, J. M., Schuurs, A. H. W. M. \& Simpson, M. V. (1964). A cell-free amino acid-incorporating system from Saccharomyces cerevisiae. Variation in ribosomal activity and in RNA synthesis during logarithmic growth. Biochemistry 3, 959-967.

Matile, P., Moore, H. \& Robinow, C. F. (1969). Yeast cytology. In The Yeasts, p. 272. Edited by A. H. Rose \& J. S. Harrison. London: Academic Press.

Paltauf, F. \& Schatz, G. (1969). Promitochondria of anaerobically grown yeast. II. Lipid composition. Biochemistry 8, 335-339.

Schatz, G. \& SaltzGaber, J. (1969). Protein synthesis by yeast promitochondria in vivo. Biochemical and Biophysical Research Communications 37, 996-100I.

Schweyen, R. \& Kaudewrtz, F. (1970). Protein synthesis by yeast mitochondria in vivo. Quantitative estimate of mitochondrially governed synthesis of mitochondrial proteins. Biochemical and Biophysical Research Communications 38, 728-735.

Shockman, G. D. (1965). Unbalanced cell-wall synthesis: autolysis and cell-wall thickening. Bacteriological Reviews 29, 345-358.

TaKagi, M., Tanaki, T. \& Ogata, K. (I970). Functional differences in protein synthesis between free and bound polysomes of rat-liver. Biochimica et biophysica acta 217, $148-158$.

VARY, M. J., Edwards, C. L. \& STEWART, P. R. (1969). The biogenesis of mitochondria. Formation of the soluble mitochondrial enzymes malate dehydrogenase and fumarase in Saccharomyces cerevisiae. Archives of Biochemistry and Biophysics 130, 235-243.

Vary, M. J., Stewart, P. R. \& Linnane, A. W. (1970). Biogenesis of mitochondria. The role of mitochondrial and cytoplasmic ribosomal protein synthesis in the oxygen-induced formation of yeast mitochondrial enzymes. Archives of Biochemistry ond Biophysics 14r, 430-439.

Watson, K., Haslam, J. M., Veitch, B. \& Linnane, A. W. (I97I). Mitochondrial precursors in anaerobically grown yeast. In Autonomy and Biogenesis of Mitochondria and Cloroplasts, pp. I62-I74. Edited by N. K. Boardman, A. W. Linnane \& R. M. Smillie. Amsterdam: North-Holland Publishing Co.

YU, R. S. T., Poulson, R. \& Stewart, P. R. (I971). Comparative studies on mitochondrial development in yeasts. II. Mitochondrial ribosomes from Saccharomyces cerevisiae. Molecular and General Genetics II4, 339-349. 